\title{
Defining Professional Behavior: A Situational Look at Ethics in the Classrooms and Laboratories of American Colleges and Universities
}

\author{
Tina K. Ashford, \\ Macon State College \\ Macon, Georgia, USA
}

tashford@mail.maconstate.edu

\author{
Linda Davis, \\ William Woods University \\ Fulton, Missouri, USA
}

Idavis@williamwoods.edu

\begin{abstract}
This paper is designed to help identify specific behaviors that present challenging decisions for faculty in terms of questionable ethical behavior or conflicts of interest and ways to deal with the various situations. The behaviors are divided into five sections: 1) Dishonest or unethical behavior in teaching 2) Dishonest or unethical behavior in research 3) Sexual Harassment 4) Neglect of University-related duties and responsibilities 5) Unauthorized use of University facilities, equipment, materials, data, properties or service. Through the use of scenarios, a guided discussion of the various ethics involved in each scenario will be conducted. The sets will be followed by suggested ideas that may guide the practice of faculty professionals, as well as those behaviors that would constitute misconduct.
\end{abstract}

Keywords: Ethics, Professional Behavior, Interactive, Guidelines

\section{Introduction}

Unethical behavior seems to be more common in the workplace than ever before. Thanks to Enron, Martha Stewart, ImClone, and other scandals, the United States of America has been forced to analyze behavior involving ethics in the workplace. Higher Education has also been forced to examine their own behavior as awareness of high-tech cheating in the classroom, well-defined skills of plagiarizing are refined, and full-fledged term papers await those who are willing to pay. Professors, instructors and teaching assistants around the nation are also being challenged in areas of immoral, unethical and unscrupulous behavior both in and out of the classroom.

Material published as part of this publication, either on-line or in print, is copyrighted by the Informing Science Institute. Permission to make digital or paper copy of part or all of these works for personal or classroom use is granted without fee provided that the copies are not made or distributed for profit or commercial advantage AND that copies 1 ) bear this notice in full and 2) give the full citation on the first page. It is permissible to abstract these works so long as credit is given. To copy in all other cases or to republish or to post on a server or to redistribute to lists requires specific permission and payment of a fee. Contact Publisher@InformingScience.org to request redistribution permission.
The purpose of this paper and companion interactive presentation at conference is to assist faculty in developing ethical judgments through critical thinking, present research involving ethics in the classroom, and deliberation of the various situations that faculty are faced with in higher education today. Helping faculty define fundamental judgments for analyzing their behaviors within ethical situations will assist 
in refining their roles as faculty of high ethical character.

The interactive presentation at conference will present various dilemmas involving classroom ethics. Participants will be asked to exercise their own judgment and deliberations of the situations. They will be challenged to discuss solutions to the various situations that are often presented within professional situations. The feedback results from the presentation, while informal, will be used in our study of ethics, codes of professional conduct and utilized in a full paper to be published later.

\section{Development of Scenarios}

A few years ago, the Boston Globe published a story about Joseph J. Ellis, a distinguished faculty at Mount Holyoke College, a Pulitzer Prize-winning historian, and author of a bestseller. Mr. Ellis had fabricated stories of his tour in Vietnam not only to other colleagues, but to his students during courses on Vietnam and American culture (Wassyng Roworth, 2002). What seemed most troublesome, however, was that Ellis was a renowned faculty and publisher. Why would he fabricate and embellish his stories? With so much at stake, it seemed absurd. Several noted the severity of the act involving his dishonesty due to the fact he had breached the trust placed upon him by society. Faculty members hold a certain inalienable power to influence through their use of knowledge. If that power is found to be flawed or worse yet, totally false, the overall worth of faculty and the position they hold is diminished. Perhaps Wilcox and Ebbs (1992) best presents the position in stating:

"Colleges and universities are custodians of knowledge. Because the possession of knowledge is the source of power, understood here as the ability to influence decisions in contemporary society, these institutions are also the gateway to power, significantly affecting the quality of economic and social life throughout the world. Thus, insofar as colleges and universities create and disseminate knowledge within a particular society, they are institutions with moral responsibilities to maintain the well-being of that society.” They often hold a devotion and conviction for the "worth and dignity of the advancement of knowledge", and recognized the "special responsibilities placed upon them" (ASCCC, 2002).

In the tradition of keeping with these rights and responsibilities faculty often conduct themselves under the guise of unspoken rules granted in exchange for ethical behavior governing deliverance of education, conduct with students and restraint from self-interest and selfindulgences within the academic community. This level of self-governance presents a certain amount of power and influence within a society.

Outspoken critics of faculty self-governance, such as Michael Lewis (1997. p. 144), have tested this view of higher education in America as “a con artist's heaven” and demands, “...an end to the permissiveness that comes of the remarkable capacity for delusion and denial possessed by so many academics. He calls for "an end to the injury that all this visits upon students and others who have naively placed their faith in the professoriate's self-proclaimed honorable intentions. The ivory tower of academia, much like society, is being faced with behaviors and situations that are calling individuals to face ethical dilemmas and more importantly to resolve the issues that define an institution.

Left at task to monitor ethical behavior within higher education are organizations such as The American Association of University Professors (AAUP). AAUP has long deemed ethics as one of their most important topics. They have defined and revised over the years an Ethics Statement that clearly notes that with the role of being members of the professional faculty community comes certain obligations. The AAUP further states, "The intellectual virtues of 
being open-minded, fair, honest and objective in the consideration of differing views, being thorough in research, avoiding the manipulation of data, reaching a well-reasoned viewpoint and the like, should all be fostered within the intellectual character of the faculty member."

Although these issues are ever apparent in higher education, research on "faculty behavior has focused on "hot topics" such as sexual harassment and largely ignored the more daily ethical dilemmas involved in teaching and instructor-student interactions" (Korschgen and Morgan, 2001) . Korschgen and Morgan noted a limited number of research articles dealing with students' perceptions of faculty behavior. One of their more robust research studies examined the differences in professors' and students' perceptions of the ethicalness of faculty behavior. The study was conducted by involved responses of 115 professors and 157 undergraduates to a 16 item survey selected from a previously defined list by noted ethics researchers Tabachnick, Keith-Spiegal and Pope (1991) regarding faculty behavior. Korschgen and Morgan found significant differences on 4 of the 16 items/behaviors. Faculty saw utilizing an easy test to ensure popularity as more unethical than did the students $(t=-5.04, p<.001)$. Two other items that gained significance as more unethical by faculty than students involved accepting a textbook rebate $(\mathrm{t}=-5.14, \mathrm{p}<.001)$ and using profanity in lectures $(\mathrm{t}=-6.69 . \mathrm{p}<.001)$. Although not significant, there was a strong tendency for faculty to view sexual involvement with a student more unethical than student views of this behavior $(\mathrm{t}=-2.91, \mathrm{p}=.004)$.

Ethics concerning the interaction between a faculty member and a student has gained more attention over the years as sexual harassment has gained momentum. There seems to be a disdain for those who use their power or authority for personal gain or control over students who are in a vulnerable position especially while in the academic setting. "It is a fundamental ethical principle that individuals in power and authority should not use their advantaged position for their own gain or to advance their own self- interest. In light of the fact that the educational profession is one in which trust between faculty member and student best maximizes the results of the learning experience, it is especially reprehensible for faculty to use their power and authority for such self-gratification.” (AAUP)

Although students' view of faculty-student relationships was not significant, they did note the use of old lecture notes $(\mathrm{t}=3.66, \mathrm{p}<.001)$ as more unethical than did faculty, and had a strong trend toward viewing the breaking of confidence $(\mathrm{t}=2.85, \mathrm{p}=.005)$ and the teaching of un-mastered material $(\mathrm{t}=2.89, \mathrm{p}=.004)$ as more unethical than did the faculty.

Overall, it was noted more differences between students and faculty than previous research would suggest (Keith-Spiegel, Tabachnick, \& Allen, 1993). This came as no surprise since the significant issues viewed by students involved their own self-interest (impact of lectures, breaking of confidence). Faculty, however, were more aware of factors that directly affect their positions such as "emergency hires," and textbook rebates that refocus the moral principles from their self-behaviors to reasons underlying the actions.

Students appear less distracted by issues such as allowing likeability to influence grading, giving easy tests for popularity sake, and sexual relations between faculty and students as mentioned earlier. However, although there was a difference of degree, both faculty and students viewed most of the behaviors as unethical. For instance, both faculty and students ignoring evidence of cheating and insulting a student in his/her absence as strongly unethical.

Demanding more ethical character from the educational sector, as it is with the public sector, is often fraught with challenges. Firing or even reprimanding a tenured professor is often laden with various layers of legal loopholes. The tenure title, although initially granted to help protect academic freedom, often disguises itself as a safety net for unethical, immoral or dishonorable conduct. Firing a tenured faculty may be a "lengthy, expensive, and bitter process” as Rutgers University found in the case with Joseph San Filippo, Jr., a former professor 
of chemistry. (Mooney, 1994). Mr. Filippo, it contends, had engaged in numerous unethical behaviors many involving students along with fraudulent employment reports. Although the behaviors seemed an obvious breach of the moral and ethical code in place which should have expedited his dismissal, the final determination took over 250 hours of hearings and lasted more than 46 days.

Cases such as this give credence to Michael Lewis, contention that the academia of higher education is the 'con artist's heaven'. "It is as well an asylum for those whose lame incompetence would not long be tolerated in less-protected occupational environs." Furthermore, as noted by the AAUP in 1915 "This social compact between society and the members of a learned profession must be renewed in each generation through education of both the members of the profession and the public about the traditions and ethics.”

Many will argue that most ethical situations can be viewed from different perspectives and that cultural difference, moral principles and even societal differences all affect scrutiny of moral behavior. With this in mind, this paper explores these ideas with the goal of defining what is and is not appropriate behavior in the classroom and how to resolve ethical issues as they arise.

In an attempt to manage the areas of concern when studying professional behavior and ethics in the setting of higher education, categories were developed in which various scenarios could be divided into. The 5 categories agreed upon are:

\section{Dishonest or unethical behavior in teaching}

\section{Dishonest or unethical behavior in research}

\section{Sexual Harassment}

\section{Neglect of school-related duties and responsibilities}

\section{Unauthorized use of facilities, equipment, materials, data, properties or service}

During preliminary research on this subject, faculty members at Macon State College, Macon, Georgia and William Woods University, Fulton, Missouri were informally interviewed to identify areas of concern to address in our paper. To help convey the purpose of this paper and interactive presentation, the following is a condensed list of scenarios that are being evaluated for inclusion:

1. Researcher manipulates results to reflect expected or desired outcomes.

2. Guest speaker uses class time to advance their political/religious cause.

3. Faculty self-plagiarizes own papers to enhance professional development activities.

4. Faculty uses class time to sell products or to advance political/religious cause.

5. Faculty places non-academic material on their school-hosted website.

6. Faculty uses school owned equipment for personal/business use.

7. Faculty discusses a student's personal problem/information with colleagues in a public/private setting.

8. Faculty uses school's listservs/distribution lists for personal/business gain.

9. Faculty republishes student work as their own or without proper citation.

10. Faculty uses employee ID to receive student benefits.

11. Faculty uses offer from other school to negotiate higher salary. 
12. Faculty uses school software for personal/ home use.

13. Faculty gives a good recommendation for an inadequate co-worker in order to get rid of the employee.

14. Faculty use students to research and /or complete projects that will benefit the faculty's personal business or professional vitae.

15. University uses "self-made-majors" as a way of encouraging students to attend their college knowing most of the majors are not valid.

16. Slightly alter data in order to influence outcome of reported diversity reports so the University will appear more in line with national averages.

17. Inflate requests for reimbursement of expenses or for pay.

18. Faculty sell a required piece of technology to the students at slightly over cost and pocket the profit justifying it as saving the student an unnecessary trip.

19. Faculty accepts a gift from a vendor who does business with the college (but also with the faculty on a personal level).

20. Faculty member initiates personal relationship with student.

21. Faculty makes racial/sexist remarks during class

22. Faculty takes students out to a bar after evening class/end of the semester.

23. Faculty requires students to purchase a textbook they wrote.

24. Faculty holds two full-time positions at different schools.

25. Faculty doesn’t keep posted office hours.

26. Faculty doesn't grade final papers/exams when grade received won't influence grade earned for the class.

27. Faculty accepts gifts from students that may or may not influence grades.

28. Faculty uses travel/conference for personal pleasure trip

29. Faculty inflates travel funds used for conference.

30. Unauthorized use of University facilities, equipment, materials, data, properties, or services.

Time permitting, as each set of scenarios is presented, a guided practice for analyzing the behavior and suggested ideas that may direct the practice of faculty professionals in these areas is explored. Behaviors that would constitute misconduct are examined so that faculty can effectively manage or even avoid situations of this nature.

\section{Conclusion}

Although guidelines for avoiding unethical conduct will be suggested, it will also be noted the difficult challenge faced in defining a set of rules to follow in order to maximize ethical behavior due to the fact that colleges regard ethics and the behaviors that define ethics, very differently. Furthermore, freedom of speech, academic freedom, tenure and other faculty freedoms often intimidate administrative disciples on faculty. Our goal is more importantly to help faculty be aware of situations that may present themselves as unethical behavior and help guide them in managing or avoiding those situations. It is our intention to provide assistance understanding this topic in a useful, non-judgmental and interesting manner. 
We look forward to the continued research and presentation of this important topic. We invite questions or comments which may be directed to either author.

\section{References}

Academic Senate for California Community Colleges. (2002). Faculty Ethics: Expanding the AAUP Ethics Statement. Retrieved October 22, 2005 from http://www.academicsenate.cc.ca.us/Publications/Papers/ethics.html

American Association of University Professors. Retrieved October 22, 2005 from http://www.aaup.org/statements/Redbook/Rbethics.htm

Blevins-Knabe, B. (1992). The ethics of dual relationships in higher education. Journal of Ethics and Behavior, 2.

Counelius, J. S. (1993). Toward empirical studies on university ethics: A new role for institutional research. Journal of Higher Education, 64.

Keith-Spiegel, P., Tabachnick, B. G., \& Allen, M. (1993). Ethics in academia: Students' views of professors' actions. Ethics and Behavior, 3(2), 149-162.

Korschgen, A. J. \& Morgan, B. L. (2001). The ethics of faculty behavior: Students' and professors' views. College Student Journal. 35(3).

Lewis, M. (1997). Poisoning the ivy: The seven deadly sins and other vices of higher education in America. M.E. Sharpe.

Mooney, C. J. (1994). Dismissals 'for Cause': Removing a tenured professor can be a lengthy, expensive, and bitter process. The Chronicle of Higher Education, p. A17

Tabachnick, B. G., Keith-Spiegel, P., \& Pope, K. S. (1991). Ethics of teaching: Beliefs and behaviors of psychologists and educators.

Wassyng Roworth, W. (2002). American Association of University Professors. Professional Ethics, Day by Day. Retrieved October 22, 2005 from http://www.aaup.org/publications/Academe/2002/02JF/02jfrow.htm

Wilcox, J. R. \& Ebbs, S. L. (1992). The leadership compass. Values and ethics in higher education. ERIC Clearinghouse on Higher Education. Washington DC. George Washington Univ. Washington DC. School of Education and Human Development. Also available from http://www.ericdigests.org/1992-1/compass.htm.

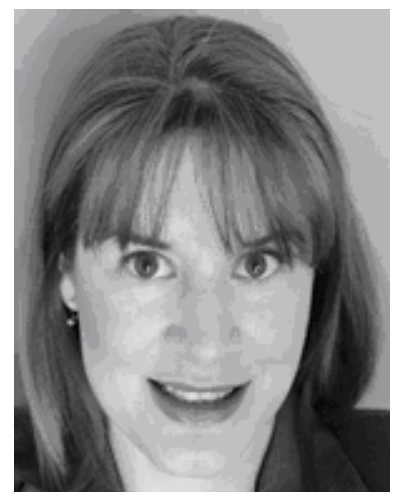

\section{Biographies}

Tina Ashford is a tenured Assistant Professor at Macon State College in Macon, Georgia. Her primary areas of responsibility include curriculum development of introductory, hardware, and history of Information Technology courses. Tina has actively presented at regional and national conferences for over 12 years and is known as a lively and informative presenter. She has been an invited guest lecturer at numerous local civic meetings and interviewed by publications such as "The Academic Leader". Tina writes a tech-help column for a regional newspaper in central Georgia. She also enjoys conducting faculty development seminars on the subjects of e-portfolios and professional behavior. 


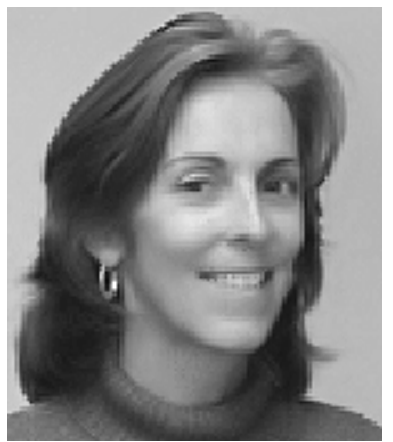

Linda Davis is an Associate Professor of Computer Information Systems at William Woods University in Fulton, Missouri. Dr. Davis' primary areas of expertise include The Effects of Student Learning Styles, Perceptions of Online Learning and Demographics on Distance Education Outcomes in Higher Education and web site development. Linda has extensive presentation experience and enjoys sharing her expertise at regional and national conferences, in addition to local community organizations. Linda has been awarded the 2003 Missouri Governor's Award for Teaching Excellence. 